\title{
Evidence for Century-Timescale Acceleration in Mean Sea Levels and for Recent Changes in Extreme Sea Levels
}

\author{
Philip L. Woodworth \\ National Oceanography Centre, Joseph Proudman Building, 6 Brownlow Street, \\ Liverpool L3 5DA, United Kingdom \\ Melisa Menéndez \\ Environmental Hydraulic Institute "IH Cantabria”, Universidad de Cantabria, \\ 39005 Santander, Spain \\ W. Roland Gehrels \\ School of Geography, Earth and Environmental Sciences, University of Plymouth, \\ Plymouth PL4 8AA, United Kingdom
}

Corresponding Author: Philip L. Woodworth (tel. 44-151-795-4800, fax. 44-151-795-4801, email plw@pol.ac.uk)

\begin{abstract}
Two of the most important topics in Sea Level Science are addressed in this paper. One is concerned with the evidence for the apparent acceleration in the rate of global sea level change between the $19^{\text {th }}$ and $20^{\text {th }}$ centuries and, thereby, with the question of whether the $20^{\text {th }}$ century sea level rise was a consequence of an accelerated climate change of anthropogenic origin. An acceleration is indeed observed in both tide gauge and saltmarsh data at different locations around the world, yielding quadratic coefficients ' $c$ ' of order $0.005 \mathrm{~mm} / \mathrm{year}^{2}$, and with the most rapid changes of rate of sea level rise occurring around the end of the $19^{\text {th }}$ century. The second topic refers to whether there is evidence that extreme sea levels have increased in recent decades at rates significantly different from those in mean levels. Recent results, which suggest that at most locations rates of change of extreme and mean sea levels are comparable, are presented. In addition, a short review is given of recent work on extreme sea levels by other authors. This body of work, which is focused primarily on Europe and the Mediterranean, also tends to support mean and extreme sea levels changing at similar rates at most locations.
\end{abstract}

Keywords: Sea level accelerations, Extreme sea level changes, Tide gauge and saltmarsh measurements, Data archaeology. 


\section{Introduction}

This paper addresses two of the most important questions in Sea Level Science. The first question is, given that global sea level has risen at a rate of approximately $1.7 \mathrm{~mm} /$ year during the $20^{\text {th }}$ century, was that value significantly larger than in previous centuries? If the $20^{\text {th }}$ century sea level rise was primarily a consequence of anthropogenic climate change, as suggested by the assessments of the Intergovernmental Panel on Climate Change (IPCC), then one would have expected there to have been a long-term acceleration in the rate of rise.

The second question concerns whether evidence exists for significant differences between rates of change of extreme and mean sea levels. Scientists usually focus on the latter, as changes in mean values are associated closely to climate-related processes including oceanic steric change, variations in ice sheet, ice cap and glacier mass balance, and hydrological exchanges between land and ocean. However, people more concerned with impacts of sea level change, including those people who live near to the coast, tend to be interested primarily in evidence for changes in extreme sea levels.

The understanding of historical mean sea level (MSL) change, and the accurate prediction of potential future MSL rise, is a difficult task (as demonstrated by other papers in this volume). However, if extremes were to be observed to change at different rates, on average, to mean levels, then their understanding and prediction would present us with an even more difficult problem.

\section{Century-Timescale Acceleration in Sea Level}

One advantage in the study of accelerations, rather than of linear trends, in MSL is that the vertical land movements (VLMs) of the land on which the tide gauges (sea level stations) are situated, and which contribute to the observed relative sea level changes, are in many cases much lower in frequency than the ocean-related signals of interest. Therefore, the quadratic (or higher order) time-dependence of a sea level record should be associated primarily with ocean change rather than land movement. This situation applies when the main geological process responsible for VLM is Glacial Isostatic Adjustment (GIA). However, it will clearly not be the case when the area around a tide gauge experiences earthquakes or when local groundwater pumping of water or hydrocarbons takes place (see Emery and Aubrey 1991 for many examples of contributions of VLMs to sea level records).

On the other hand, there is a difficulty in answering our first question (whether the sea level changes of the $20^{\text {th }}$ century were significantly larger than in previous centuries and, therefore, whether accelerations in sea level have taken place) due to the limited number of long term sea level records spanning two or three centuries. Most long tide gauge records are from northern Europe, constructed from measurements of high and low waters (or sometimes high waters alone) before the invention of automatic tide gauges in the mid- $19^{\text {th }}$ century enabled the measurement of the full tidal curve and a computation of MSL. Figure 1(a) is adapted from a similar figure shown in Woodworth (1999) and the IPCC Third 
Assessment Report (TAR, Church et al. 2001). Important modifications are that the Amsterdam record has been extended with the use of data from Den Helder, the Brest time series has been extended back to the $18^{\text {th }}$ century (Pouvreau 2008; Wöppelmann et al. 2008), the Liverpool time series now attempts to reflect MSL rather than mean high water change, and the Stockholm record of Ekman (1988) has been updated using data from the Permanent Service for Mean Sea Level (PSMSL, www.psmsl.org, Woodworth and Player 2003). If one applies a secondorder fit $\left(\mathrm{a}+\mathrm{bt}+\mathrm{ct}^{2}\right.$ where ' $\mathrm{t}$ ' is time and ' $c$ ' must be doubled to give acceleration) to each time series, then quadratic coefficients ' $c$ ' of order 0.005 $\mathrm{mm} /$ year $^{2}$ are obtained, all the records shown providing evidence for a long term acceleration in sea level, and suggesting that the acceleration commenced around the end of the $19^{\text {th }}$ century or a little later. There is only one other northern European record of similar length known to us; that record is from Kronstadt, Russia spanning 1773-1993 which had many difficulties in its construction (Bogdanov et al. 2000).

There are no records of similar length elsewhere. However, if one settles for somewhat shorter records and examines time series from the PSMSL Revised Local Reference data set which commence before 1871 and have at least 100 years of data since that time, then one obtains 4 records from the Baltic and North Sea coasts of Germany. These yield ' $c$ ' values between 0.0005 and 0.0062 $\mathrm{mm} /$ year $^{2}$ for the mid- $19^{\text {th }}$ century onwards, those values for the German Baltic stations being essentially zero. Outside of Europe, the same selection criteria provide only two additional records from San Francisco and New York which yield 'c' values of 0.0069 and $0.0038 \mathrm{~mm} /$ year $^{2}$ respectively since the $1850 \mathrm{~s}$, consistent with the acceleration inferred by Maul and Martin (1993) for 1846 onwards for Key West, America's longest, if somewhat gappy, record. These six shorter records are shown in Figure 1(b), and have superimposed separate linear fits to their $19^{\text {th }}$ and $20^{\text {th }}$ century data as a guide to any acceleration. Altogether, Figure 1 $(a, b)$ suggests that a century-timescale acceleration applies to the northern hemisphere in general, a conclusion further confirmed by the study of saltmarsh information discussed below. However, the magnitude of the acceleration varies between stations. Furthermore, it can be seen that for tide gauge records with start dates in the mid- $19^{\text {th }}$ century or later, it is much more difficult to have confidence in the evidence for acceleration between the centuries, given the amount of interannual and decadal variability present in all records (as discussed by Douglas 1992 and other authors, as is evident visually from Figure 1(a,b), and from a comparison of the formal errors on 'c' values given in the captions to Figures 1(a) and (b)).

Several studies have been published which have presented 'reconstructions' of 'global' sea level change, with the use of both long and short records combined in various ways (Church and White 2006, 2011; Jevrejeva et al. 2006). Results tend to support findings from the individual long records. Church and White (2011) have recently updated their 2006 reconstructions using Empirical Orthogonal Functions (EOFs) of ocean variability as observed by altimetry since 1993, together with coastal tide-gauge information. They obtained a global-average acceleration of sea level between 1880 and 2009 of $0.009 \pm 0.003 \mathrm{~mm} /$ year $^{2}$ (quadratic coefficient ' $c$ ' $=0.0045 \pm 0.0015 \mathrm{~mm} /$ year $^{2}$ ). Jevrejeva et al. (2006) derived time series of regional and global sea level by combining both short and long tide gauge records from the early part of the $19^{\text {th }}$ century onwards with the 
use of a 'virtual station' technique, and demonstrated changes in global sea level trend between the $19^{\text {th }}$ and $20^{\text {th }}$ centuries similar to those of Church and White (see comparisons of these analyses in Woodworth et al. 2009a). Jevrejeva et al. (2008) attempted to extend the reconstruction analysis over three centuries with the use of the small number of long records, concluding that the long-term acceleration could have started nearer to the beginning of the $19^{\text {th }}$ century rather than at its end, as preferred by other studies.

As might be anticipated, such a period of long-term acceleration consists of shorter periods with greater acceleration, or even deceleration. In the review by Woodworth et al. (2009a), it was pointed out that most sea level data originate from Europe and $\mathrm{N}$ America and both sets display evidence for a positive acceleration, or 'inflexion', around 1920-1930 and a negative one around 1960. These inflexions are the main contributors to the long-term accelerations mentioned above, and to the decelerations one tends to find using $20^{\text {th }}$ century data alone (as discussed by Woodworth 1990, Douglas 1992 and Holgate 2007). However, all of these characteristic features are not found in records from all parts of the world. For example, Raicich (2007) presented an extended (backwards) time series for Trieste spanning 1875 onwards which shows an overall secular trend of $1.3 \pm 0.1 \mathrm{~mm} /$ year with little evidence for long-term acceleration, the downturn after the 1960s, seen particularly strongly in many Mediterranean records (Tsimplis and Baker 2000), being the single characteristic feature of the record.

Until the 1990s, the only evidence for accelerations came from tide gauge data and so could not be claimed to be necessarily 'global'. Since that time, precise radar altimeter data from space have become available (Fu and Cazenave 2001). One notes that the high rates during the 1990s, which represent an acceleration compared to those of the $20^{\text {th }}$ century as a whole, are of similar magnitude in both tide gauge and altimeter data. This recent acceleration has been reported by Holgate and Woodworth (2004), White et al. (2005) and Prandi et al. (2009), and has been discussed by Rahmstorf et al. (2007). Whether it represents the start of a long term increase in the rate of sea level rise, rather than decadal variability, remains to be seen.

If long, continuous records of sea level are not available from a region, then it becomes especially important to make maximum use of short periods of historical information where they exist. In particular, this applies to the relatively datasparse southern hemisphere. The essential factor in such studies is that the historical tide gauge benchmarks must have survived to the present day. For example, Hunter et al. (2003) made use of measurements at Port Arthur, Tasmania from 1841-2, together with more recent measurements, with the conclusion that sea level had risen at an average rate of $1.0 \pm 0.3 \mathrm{~mm} /$ year, after a small correction for vertical land movement. Woodworth et al. (2010a) performed a similar analysis at Port Louis, Falkland Islands where James Clark Ross measured sea levels in 1842. The long-term rate of change of sea level was estimated to have been $0.75 \pm 0.35 \mathrm{~mm} /$ year between 1842 and the mid-1980s, after correction for air pressure effects and for vertical land movement due to GIA.

These values of sea level change since the mid- $19^{\text {th }}$ century do not provide insight into long term acceleration, but they do enable a baseline of change against which 
present day rates can be compared. For example, sea level has been rising at Spring Bay (near to Port Arthur) at a rate of $3.4 \mathrm{~mm} /$ year since 1991 (uncorrected for vertical land movement which is likely to be small, Table 5 of NTC 2009), while at Port Stanley (near to Port Louis) the rate of sea level rise observed since 1992, when the modern Stanley gauge was installed, has been $2.51 \pm 0.58$ $\mathrm{mm} /$ year, after correction for air pressure and GIA (Woodworth et al. 2010a). Figure 2 indicates this recent acceleration in the Falkland Islands. These larger rates over the last one or two decades are consistent with the picture of a general recent global acceleration with particular contributions from the tropics and from higher southern latitudes (Merrifield et al. 2009a). Other recent studies of southern hemisphere sea level change that have made use of sections of historical information include those of Watson et al. (2010) and Testut et al. (2006), although these investigations are limited to study of $20^{\text {th }}$ century changes. Testut et al. (2010) have recently studied changes at Saint Paul Island in the southern Indian Ocean, finding changes in sea level consistent with zero since 1874, although without a vertical land movement correction which is problematical at that location.

Alongside study of continuous tide gauge records, and of short sets of data separated by a long period of time, another important category to emphasise is that of gauges which once had sustained, continuous records but which were discontinued for one reason or other. Woodworth et al. (2009b) have shown how useful information on sea level trends can be obtained from the long historical records in Takoradi (Ghana), Aden (Yemen) and Karachi (Pakistan) separated by many decades from data obtained from newly installed instruments. Similar installations of new equipment at sites with long records must form a community priority.

It is well-known that the PSMSL data set is weighted considerably towards the northern hemisphere (see http://www.psmsl.org/products/data coverage/). Although it is possible that other historical tide gauge data of the types described above may be discovered in archives and analysed (a process called 'data archaeology'), thereby supplementing the PSMSL data set, it is clear that such information will always be limited, especially in the southern hemisphere. Consequently, other types of sea level information have to be investigated, and their data sets combined with those from tide gauges, thereby ensuring that our knowledge of sea level change over the past two or three centuries is more representative globally.

The complementary techniques might provide sea level time series which are either longer than those of tide gauges or come from regions where no gauge records exist. Possible techniques include the use of archaeological sources in areas such as the Mediterranean where tidal amplitudes are small and where Roman and other historical artifacts constructed at known heights relative to former sea levels still exist. In tropical areas, high-resolution information from corals can be used to deduce sea level changes over past centuries with sufficient precision to detect accelerations on multi-decadal timescales. Lambeck et al. (2010) provide a review of both areas of research.

Saltmarshes offer another source of sea level information and suitable marshes exist throughout the mid- to high-latitudes. Research has shown that in many 
circumstances the saltmarshes and nearby tide gauges provide similar information on timescales of decades to centuries, with the saltmarsh data appearing to a great extent to mimic a gauge record with a low-pass filter of approximately a decade depending on the location (Milne et al. 2009). The surface of a saltmarsh is close to the high tide level so that, when sea level rises over decades, sediments accumulate and the marsh surface builds up vertically. A history of sea level rise can then be reconstructed using micropalaeontological and sediment dating techniques, and the use of a 'transfer function' which depends on an assumption that the vertical distribution (relative to a chosen tide level) of fossil remains in the historical and modern marshes are the same. The need for continuous sedimentation means that marsh areas prone to erosion and highly fluctuating sedimentation rates, such as the lower saltmarsh and areas near tidal creeks, are to be avoided.

Figure 3 presents a compilation of findings from western Greenland (Long et al. 2010), northern Spain (Leorri et al. 2008), Tasmania (Gehrels et al. in prep.), Iceland (Gehrels et al. 2006), New Zealand (Gehrels et al. 2008), Connecticut (Donnelly et al. 2004), North Carolina (Kemp et al. 2009) and Nova Scotia (Gehrels et al. 2005) (the individual papers may be consulted for analysis details, see also Woodworth et al. 2009a and Mitchum et al. 2010). Most of the saltmarsh records contain a rapid acceleration or 'inflexion' as indicated in this schematic compilation. The abruptness of the accelerations seen in the records has been often remarked upon and may be partly an artifact of the use of different dating methods at different points in the record. Nevertheless, the general character of acceleration seen in the northern European tide gauges can also be seen in the various saltmarsh data, although the changes of trend between the $19^{\text {th }}$ and $20^{\text {th }}$ centuries suggested by Kemp et al. (2009), for the North American stations at least, would correspond to 'c' values of approximately 0.008 to $0.011 \mathrm{~mm} / \mathrm{year}^{2}$ which is approximately twice that inferred from the tide gauges. This may be due to the longer duration of these records and/or the 'filtering' effect mentioned above. However, if compaction has affected the sediments, the saltmarsh records may overestimate the sea level acceleration. Checks and, if required, corrections for compaction (e.g. through measurements of bulk density) are critical for establishing accurate sea level records from saltmarsh sediments (e.g. Gehrels et al. 2008). That said, the records in Figure 3 are compaction-free or have been corrected for compaction.

All records, except Greenland and Iceland, show a clear inflexion at the end of the $19^{\text {th }}$ century or the beginning of the $20^{\text {th }}$ century. The inflexion is most pronounced in the southern hemisphere records. This could be in line with the theory of sea level 'fingerprinting' (Mitrovica et al. 2001, 2010) if Greenland is a source of the excess sea level rise recorded in the $20^{\text {th }}$ century compared to preceding centuries. Similarly, this theory could provide an explanation why the inflexion is not present in the records close to the Greenland melt source (Iceland and western Greenland itself). On the other hand, it has been suggested that oceanic steric effects and changes in the ocean circulation may obscure any detectable sea level fingerprint signal (cf. Wake et al. 2006). This notwithstanding, the geographical pattern of the inflexion provides an interesting Greenland-melt working hypothesis which requires further testing. It is clearly important to use an expanded data set to study further the different timings of accelerations in different locations and by different methods (saltmarsh, corals, 
tide gauge, archaeology). Accelerations or inflexions which occur well before the $20^{\text {th }}$ century are of particular interest as they suggest a natural rather than an anthropogenic cause. Those which have occurred in the more highly-instrumented modern era demand consistency between measurement techniques so as to have confidence in the various measurement methods.

What may have caused the long-term acceleration between the $19^{\text {th }}$ and $20^{\text {th }}$ centuries seen in many parts of the world? Ultimately, an answer has to come from proper appreciation of the changing budget of oceanic steric, cryospheric and hydrological contributions due to natural (e.g. volcanic, solar) and anthropogenic forcings. Budgets have been discussed extensively recently (Domingues et al. 2008; Cazenave 2009; Church et al. 2010, 2011). Their findings are very encouraging. However, these discussions are from the perspective of the last few decades when most observational data sets have been of adequate quality. Consideration of budgets over longer timescales becomes more of a climate, glaciological and ocean circulation modelling exercise, and modelling undertaken so far has been unable to describe these features adequately.

One interesting (if speculative) relevant and recent study is that of Miller and Douglas (2007) who discussed evidence for a long-term deceleration in North Atlantic gyre strength (spin down), represented by decreasing air pressures near to the centre of the sub-tropical gyre, and for a connection to an acceleration in the rate of sea level change at the eastern boundary. A similar inference was made from the North Pacific data, although the poorer quality air pressure fields available for that ocean prevented as firm a set of conclusions as for the North Atlantic. Their analysis was limited to data sets from the late- $19^{\text {th }}$ century onwards. However, Woodworth et al. (2010b) recently showed that the relationship holds, at a qualitative level for the North Atlantic, for the last two and a half centuries. Therefore, it is clear that a considerable amount of ocean and climate modelling remains to be performed in order to understand better the various contributors to global-average sea level rise and to the spatial redistribution of water.

\section{Changes in Extreme Sea Levels}

Similar considerations of data availability affect studies of extreme sea level changes. However, in this case the problems are much greater. For many years, most countries have contributed MSL information to the PSMSL. Such data were often regarded as having little commercial or national security importance, and hence could be shared internationally. However, the raw data (typically hourly values of sea level) were often restricted. Nowadays, the situation is much improved, standard formats for international data exchange have been agreed, and there are no technical reasons why data sets larger than the MSL ones cannot be submitted to, and quality controlled and archived by, data centres. Nevertheless, it remains the case that no raw data are shared by a number of countries with long coastlines (notably India, China and Russia).

A further factor related to data availability concerns the changes of tide gauge technology during the past half-century. Nowadays, most tide gauges have 
electronic data loggers with sea levels transmitted via telephone or satellite to data centres (although at different frequencies in different countries). In previous years, most tide gauges comprised stilling wells with floats connected to paper charts that required relatively simple inspection (for noting of high and low waters and thereby computation of Mean Tide Levels) or digitisation (for extraction of hourly values and computation of Mean Sea Levels). In some countries, charts remain undigitised, or worse have been destroyed. The consequence is that, while a small number of long records of hourly (or similar) sea levels exist, the vast majority of useful available records span the past few decades only. One must recognise the excellent work of international programmes and data centres (notably the University of Hawaii Sea Level Center), the work of which through programmes such as TOGA (Tropical Ocean Global Atmosphere) and WOCE (World Ocean Circulation Experiment) has provided enhanced data sets for the latter part of the $20^{\text {th }}$ century (Woodworth et al. 2003).

When equipped with such a dataset of hourly sea levels from typically the 1970s onwards, one can ask if there is evidence for extremes having changed at different rates to MSL. A first attempt to address this question on a quasi-global basis was made by Woodworth and Blackman (2004) and has since been updated and extended by Menéndez and Woodworth (2010) who made use of a quasi-global sea level data set called GESLA (Global Extreme Sea Level Analysis) compiled through a collaborative activity of the Antarctic Climate and Ecosystems Cooperative Research Centre (ACE CRC), Australia and the National Oceanography Centre (NOC), Liverpool, UK.

They applied a non-stationary extreme value analysis to the monthly maxima of total elevations and surges for the period 1970 onwards, while a small subset of the data was used to study changes over the $20^{\text {th }}$ century. The analyses demonstrate the magnitude and timing of the seasonal cycle of extreme sea level occurrence, the magnitude of long-term trends in extreme sea levels, the evidence for perigean and nodal astronomical tidal components in the extremes, and the relationship of the interannual variability in high water levels to other ocean and atmosphere variations as represented by climate indices.

Extreme sea levels were found to have increased at most locations around the world, as suggested by many anecdotal reports of increased coastal flooding. However, the subtraction from the extreme sea levels of the corresponding annual median sea level was found to result in a reduction in the magnitude of trends at most stations, leading to the conclusion that much of the change in extremes is due to change in the mean values. This is clearly an important conclusion for coastal planners, if that conclusion applies also to the future, as predictions of MSL change are difficult and uncertain enough without additional uncertainties being introduced with regard to projected extremes.

This finding is illustrated in Figure 4 which shows trends in the $99 \%$ percentiles of sea level, as measured (top) and with median sea level for each year removed (middle). The red dots at many tide gauge locations in the upper figure demonstrate the generally positive trends in extreme sea levels in recent decades. However, most red dots disappear in the middle figure when median sea levels are subtracted. Meanwhile, the bottom figure indicates that trends in $99 \%$ percentiles of non-tidal residuals (where mean residual is defined to be zero for each year and 
so 'residual' can be considered as a 'surge' component, see Menéndez and Woodworth 2010 for details) are negative at many locations, providing little or no evidence for increasing storminess in general and supporting the view that increases in measured extremes (top) have been due to MSL changes.

A related finding is demonstrated by Figure 5. The upper figure indicates that extreme sea levels have become more frequent at most locations since the 1970s. However, when median sea level values are subtracted from the high percentiles, much smaller long-term changes in frequency of extreme events are found. Menéndez and Woodworth (2010) also pointed to the importance of climate variability on the extreme sea level trends, including in particular the El Niño Southern Oscillation (ENSO) and North Atlantic Oscillation (NAO).

A large number of investigations have been made of changes in extreme sea levels by other authors. However, most studies have tended to concentrate on changes at particular locations. A problem in synthesising findings from this body of work stems from the fact that each analysis is made over different timescales and with the use of different methods (percentiles, peak over threshold, generalised extreme value, joint probably, revised joint probability etc.) It is the nature of the problem when studying extremes that one is sensitive to the statistical properties of small samples, and each method employs the small amounts of data in different ways. A review of such publications has been made recently by Lowe et al. (2010), with the main conclusion once again that changes in extremes parallel those in MSL, although with exceptions to this general rule.

More recent publications, not contained in the Lowe et al. review, include the following papers, with a focus on Europe and the Mediterranean; we know of few recent papers on extreme sea levels from outside Europe since the review. Note that the following does not extend the Lowe et al. review of changes in waves, neither does it update discussion of the projected changes in $21^{\text {st }}$ century extremes. Both latter topics will be covered extensively in an upcoming IPCC special report on extreme events (IPCC 2011).

Haigh et al. (2010) used a data set obtained from 18 tide gauges on the UK and French sides of the English Channel spanning 1900-2006. Changes in the surge, tide and MSL components in the records were analysed separately and in combination. Extreme sea levels were found to increase at all sites but at rates not significantly different from those in MSL. Ullmann and Monbaliu (2010) found that the wintertime $99^{\text {th }}$ percentile of daily maximum sea level at Ostend in Belgium had increased at a rate of approximately $3 \mathrm{~mm} /$ year between 1925 and 2000 , which can be largely understood as a combination of a rise in wintertime MSL of around $2 \mathrm{~mm} /$ year and of daily maximum sea surge of approximately +1 $\mathrm{mm} /$ year. Changes in the occurrence of large surges were further studied in terms of modifications of weather régimes over the North Atlantic.

Turning to southern Europe, Lowe et al. (2010) reported that Ullmann et al. (2007) had concluded that maximum annual sea levels had risen twice as fast as MSL during the $20^{\text {th }}$ century ( 4 rather than $2 \mathrm{~mm} /$ year) in the Camargue (Rhone Delta) region of southern France, largely due to changes in the wind field in recent decades. Related publications concerned with this particular locality include Moron and Ullmann (2005), Ullman and Moron (2008) and Ullmann et al. 
(2008) who studied the relationships between air pressure, winds and storm surges in the area, and in particular the link between large surges and the negative phase of the NAO.

Marcos et al. (2009) employed data from 73 gauges covering the period 1940 onwards. The spatial distribution of extremes of tidal residuals (i.e. of non-tidal variability) was found to be well represented by those of a 2-D hydrodynamic model, although the model was found to underestimate the magnitude of the extremes. The interannual and decadal variability of extremes was found to be caused by MSL changes, with variability in both MSL and extremes being correlated negatively with the winter NAO index. Tsimplis et al. (2009) used data from 3 gauges in southern Europe (Coruña on the Atlantic coast of Spain, Malaga in the western Mediterranean and Trieste in the northern Adriatic) to study the effect of alteration of sampling frequency of the tide gauges on computed return periods of extremes. Differences of several centimeters were found in individual extremes obtained from hourly and 5-minute sampling, resulting in differences in 50 -year return period levels of decimeters (maximum difference of $38 \mathrm{~cm}$ at Trieste).

A seasonal climatology of extremes in southern Europe, including the Mediterranean, was presented by Tsimplis and Shaw (2010) who also found trends in high percentiles of hourly values to be largely removed when the $50 \%$ percentile (essentially the MSL) was removed. Letetrel et al. (2010) used hourly sea levels from Marseille for 1885-2008 and undertook a percentile analysis to investigate long-term trends of extremes. They concluded that secular variations in extreme sea levels are linked to MSL variations. However, decadal timescale variations in extremes showed differences to those in MSL. Changes in the return period levels of extremes were also studied, determining that an increase in levels had occurred since the 1970s.

In a study related to extremes but not discussing them per se, Vilibić and Šepić (2009) used data from 6 long records around Europe as representative of the region requiring each record to contain at least half a century of hourly or similar data. They investigated variability in 4 frequency bands and considered how well the sea level variability was associated with storminess in the atmosphere and variation in storm tracks.

Outside of Europe, Lowe et al. (2010) referred to the study of Bromirski et al. (2003) who undertook a study of meteorologically-forced non-tidal residuals at San Francisco since 1858, concluding that winter non-tidal residuals had exhibited a significant increasing trend since about 1950. Cayan et al. (2008) have since complemented that work, concluding that the $99.99^{\text {th }}$ percentile of measured sea level had increased considerably at San Francisco (by 20-fold since 1915) and at La Jolla (by 30-fold since 1933). Abeysirigunawardena and Walker (2008) discussed possible acceleration in MSL rise during the $20^{\text {th }}$ century at Prince Rupert in British Columbia, Canada. Sea level extremes were found to have risen at approximately $3.4 \mathrm{~mm} /$ year since 1945, which was twice the rate for MSL in that time, the additional amount of rise being suggested as due to ENSO-related regional interannual variability. This is one example of findings for which extremes appear to be rising faster than MSL. 
Turning to South America, Fiore et al. (2009) found an increase in the number and height of positive surges at Mar del Plata in Argentina during the recent decade (1996-2005) compared to the previous half-century, consistent with findings from Buenos Aires by D'Onofrio et al. (2008). Both of these analyses were consistent with a rise in MSL being the responsible mechanism. Finally, from a more worldwide perspective of information on extremes, one can point to regular annual reporting of extreme levels published in the Bulletin of the American Meteorological Society (e.g. Merrifield et al. 2009b).

Advanced methods for studying extreme sea levels have also been published. For example, Mudersbach and Jensen (2010) developed a method which has some similarity to that described in Menéndez and Woodworth (2010). They developed a nonstationary extreme value analysis statistical approach, based on the generalized extreme value (GEV) distribution and an L-moment parameter estimation, which was employed to derive future design water levels. In addition, methods for best estimating extremes in the future have also been published since the Lowe et al. review. Thompson et al. (2009) considered two approaches for assessing the likely impact of changes in extremes in Atlantic Canada: a dynamical modelling approach, and a method based on statistical analysis of existing sea level data. Both methods provide a satisfactory description of present day flooding probabilities for regions with large tides, but both also have limitations with regard to the computation of future changes in the distribution of levels. Hunter (2010) described a method of combining observations of present sea level extremes with the (uncertain) projections for sea level rise during the $21^{\text {st }}$ century, with assumptions that most of the changes in extremes will be due to MSL rise and that changes in variability about the mean will be small. A method of estimating exceedance probability during the $21^{\text {st }}$ century was devised, using Australian data as an example.

A number of recent publications have pointed to long-term changes in the ocean tide which are larger than one would expect from simple changes in depth due to MSL rise (Jay 2009; Ray 2009; Woodworth 2010). At the least, these papers remind us that changes in extreme sea levels can originate from more than one source (i.e. changes in tides rather than, or as well as, storm surges or MSL).

\section{Conclusions}

Studies of long term changes in 'global' mean or extreme sea levels cannot be made without data sets of high quality and as good spatial and temporal coverage as possible. In the past few years, one can point to general improvements in data sets due primarily to developments in the Global Sea Level Observing System (GLOSS) programme and to refurbishment in several ocean areas, notably in the Indian Ocean following the Andaman Tsunami in 2004. In addition, one can point to detailed 'data archaeology' exercises at a number of locations, especially in the southern hemisphere. However, it is clear that a lot of further effort in historical data acquisition and analysis is required.

A major conclusion from this body of work is that the global (or at least the northern hemisphere) ocean has experienced an acceleration in the rate of sea 
level change between the $19^{\text {th }}$ and $20^{\text {th }}$ centuries, within which have been particular periods of greater or smaller acceleration. This conclusion was first obtained by inspection of the small number of long tide gauge records but has since been verified by the research into the use of saltmarsh data. An adequate explanation for the acceleration in terms of the budget of contributors to sea level change remains to be obtained. A second conclusion has particular practical as well as scientific importance but is applicable to a shorter period of decades rather than centuries. It appears that rates of change in extreme sea levels are similar to those in mean levels, although this general finding does not apply at every location. It is to be hoped that as data sets are enhanced, both spatially and temporally, that considerably greater insight will be obtained into the long term changes of extreme and mean sea levels and also the reasons for change.

\section{Acknowledgements}

We thank Dr. Margot Saher of the University of Plymouth for assistance with the production of Figure 3. 


\section{References}

Abeysirigunawardena DS, Walker IJ (2008) Sea level responses to climatic variability and change in Northern British Columbia. Atmos-Ocean 46: 277-296, doi:10.3137/ao.460301.

Bogdanov VI, Medvedev MYu, Solodov VA, Trapeznikov YuA., Troshkov GA, Trubitsina AA (2000) Mean monthly series of sea level observations (1777-1993) at the Kronstadt gauge. Reports of the Finnish Geodetic Institute, No. 2000:1. Finnish Geodetic Institute, Kirkkonummi, Finland. $34 \mathrm{pp}$.

Bromirski PD, Flick RE, Cayan DR (2003) Storminess variability along the California coast: 1858- 2000. J Clim 16: 982-993.

Cayan DR, Bromirski PD, Hayhoe K, Tyree M, Dettinger MD, Flick RE (2008) Climate change projections of sea level extremes along the California coast. Clim Chang 87(Supplement 1): S57S73, doi:10.1007/s10584-007-9376-7.

Cazenave A (2009) Sea level: regional and global trends. In: Proceedings of OceanObs'09: Sustained Ocean Observations and Information for Society, Venice, Italy, 21-25 September 2009 (eds. Hall, J., Harrison, D.E. and Stammer, D.), European Space Agency Publication WPP-306. Downloadable from http://www.oceanobs09.net/cwp/.

Church JA, Gregory JM, Huybrechts P, Kuhn M, Lambeck K, Nhuan MT, Qin D, Woodworth PL (2001) Changes in sea level. In: Climate Change 2001: The Scientific Basis. Contribution of Working Group I to the Third Assessment Report of the Intergovernmental Panel on Climate Change, edited by J.T. Houghton, Y. Ding, D.J. Griggs, M. Noguer, P.J. van der Linden, X. Dai, K. Maskell and C.A. Johnson, Cambridge University Press, Cambridge, United Kingdom.

Church JA, White NJ (2006) A 20th century acceleration in global sea-level rise. Geophys Res Lett 33: L01602, doi:10.1029/2005GL024826.

Church JA, White NJ (2011) Sea-level rise from the late 19th to the early 21st Century. Surveys in Geophysics (this volume).

Church JA, Aarup T, Woodworth PL, Wilson WS, Nicholls RJ, Rayner R, Lambeck K, Mitchum GT, Steffen K, Cazenave A, Blewitt G, Mitrovica JX, Lowe JA (2010) Sea-Level Rise and Variability: Synthesis and Outlook for the Future. Chapter 13 in, Understanding sea-level rise and variability (eds. J.A. Church, P.L. Woodworth, T. Aarup and W.S. Wilson). Wiley-Blackwell (London).

Church JA, White NJ, Konikow LF, Domingues CM, Cogley JG, Rignot E, Gregory JM, van den Broeke MR, Monaghan A and Velicogna I (2011) The Earth's sea-level and energy budgets from 1961 to 2008. Submitted for publication.

Domingues CM, Church JA, White NJ, Gleckler PJ, Wijffels SE, Barker PM, Dunn JR (2008) Improved estimates of upper-ocean warming and multi-decadal sea-level rise. Nature 453: 10901093, doi:10.1038/nature07080.

Donnelly JP, Cleary P, Newby P, Ettinger R (2004) Coupling instrumental and geological records of sea level change: Evidence from southern New England of an increase in the rate of sea level rise in the late $19^{\text {th }}$ century. Geophys Res Lett 31: L05203, doi:10.1029/2003GL018933.

D'Onofrio EE, Fiore MME, Pousa JL (2008) Changes in the regime of storm surges in Buenos Aires, Argentina. J Coast Res 24: 260-265, doi: 10.2112/05-0588.1.

Douglas BC (1992) Global sea level acceleration. J Geophys Res 97(C8): 12699-12706.

Ekman M (1988) The world's longest continued series of sea level observations. Pure Appl Geophys 127: 73-77. 
Emery K.O., Aubrey DG (1991) Sea levels, land levels, and tide gauges. New York: SpringerVerlag. 237pp.

Fiore MME, D'Onofrio EE, Pousa JL, Schnack EJ, Bertola GR (2009) Storm surges and coastal impacts at Mar del Plata, Argentina. Cont Shelf Res 29: 1643-1649, doi:10.1016/j.csr.2009.05.004.

Fu L-L, Cazenave A (eds.) (2001) Satellite altimetry and earth sciences. A handbook of techniques and applications. Academic Press (San Diego).

Gehrels WR, Kirby J, Prokoph A, Newnham R, Achterberg E, Evans H, Black S, Scott D (2005)

Onset of recent rapid sea level rise in the western Atlantic Ocean. Quat Sci Rev 24: 2083-2100.

Gehrels WR, Marshall WA, Gehrels MJ, Larsen G, Kirby JR, Eriksson J, Heinemeier J, Shimmield T (2006) Rapid sea level rise in the North Atlantic Ocean since the first half of the 19th century. The Holocene 16: 948-964.

Gehrels WR, Hayward BW, Newnham RM, Southall KE (2008) A 20th century sea-level acceleration in New Zealand. Geophys Res Lett 35: L02717, doi 10.1029/2007GL032632.

Gehrels WR (2010) Sea-level changes since the Last Glacial Maximum: an appraisal of the IPCC Fourth Assessment Report. J Quat Sci 25: 26-38, doi:10.1002/jqs.1273.

Haigh I, Nicholls R, Wells N (2010) Assessing changes in extreme sea levels: Application to the English Channel, 1900-2006. Cont Shelf Res 30: 1042-1055, doi:10.1016/j.csr.2010.02.002.

Holgate SJ, Woodworth PL (2004) Evidence for enhanced coastal sea level rise during the 1990s. Geophys Res Lett 31: L07305, doi:10.1029/2004GL019626.

Holgate SJ (2007) On the decadal rates of sea level change during the twentieth century. Geophys Res Lett 34: L01602, doi:10.1029/2006GL028492.

Hunter J, Coleman R, Pugh D (2003) The sea level at Port Arthur, Tasmania, from 1841 to the present. Geophys Res Lett 30: 1401, doi:10.1029/2002GL016813.

Hunter J (2010) Estimating sea-level extremes under conditions of uncertain sea-level rise. Clim Chang 99: 331-350, doi:10.1007/s10584-009-9671-6.

IPCC (2011) Special report of the "Managing the risks of extreme events and disasters to advance climate change adaptation (SREX)" activity of Working Group 2 of the Intergovernmental Panel on Climate Change. To be published in 2011 (see http://ipcc-wg2.gov/AR5/extremessr/index.html).

Jay DA (2009) Evolution of tidal amplitudes in the eastern Pacific Ocean. Geophys Res Lett 36: L04603, doi:10.1029/2008GL036185.

Jevrejeva S, Grinsted A, Moore JC, Holgate SJ (2006) Nonlinear trends and multiyear cycles in sea level records. J Geophys Res 111: C09012, doi:10.1029/2005JC003229.

Jevrejeva S, Moore JC, Grinsted A, Woodworth PL (2008) Recent global sea level acceleration started over 200 years ago? Geophys Res Lett 35: L08715, doi:10.1029/2008GL033611.

Kemp AC, Horton BP, Culver SJ, Corbett DR, van de Plassche O, Gehrels WR, Douglas BC, Parnell AC (2009) Timing and magnitude of recent accelerated sea-level rise (North Carolina, United States). Geol 37: 1035-1038.

Lambeck K, Woodroffe CD, Antonioli F, Anzidei M, Gehrels WR, Laborel J, Wright AJ (2010) Palaeoenvironmental records, geophysical modelling and reconstruction of sea-level trends and variability on centennial and longer time scales. Chapter 4 in, Understanding sea-level rise and variability (eds. J.A. Church, P.L. Woodworth, T. Aarup and S. Wilson). Wiley-Blackwell (London). 
Leorri E, Horton BP, Cearetta A (2008) Development of a foraminifera-based transfer function in the Basque marshes, N. Spain: implications for sea-level studies in the Bay of Biscay. Mar Geol 251: 60-74, doi:10.1016/j.margeo.2008.02.005.

Letetrel C, Marcos M, Martín Míguez B, Wöppelmann G (2010) Sea level extremes in Marseille (NW Mediterranean) during 1885-2008. Cont Shelf Res 30: 1267-1274, doi:10.1016/j.csr.2010.04.003.

Long AJ, Woodroffe SA, Milne GA, Bryant CL, Wake LM (2010) Relative sea level change in west Greenland during the last millennium. Quat Sci Rev 29: 367-383.

Lowe JA, Woodworth PL, Knutson T, McDonald RE, McInnes K, Woth K, Von Storch H, Wolf J, Swail V, Bernier N, Gulev S, Horsburgh K, Unnikrishnan AS, Hunter J, Weisse R (2010) Past and future changes in extreme sea levels and waves. Chapter $11 \mathrm{in,} \mathrm{Understanding} \mathrm{sea-level} \mathrm{rise} \mathrm{and}$ variability (eds. J.A. Church, P.L. Woodworth, T. Aarup and W.S. Wilson). Wiley-Blackwell (London).

Marcos M, Tsimplis MN, Shaw AGP (2009) Sea level extremes in southern Europe. J Geophys Res 114: C01007, doi:10.1029/2008JC004912.

Maul GA, Martin DM (1993) Sea level rise at Key West, Florida, 1846-1992: America's longest instrument record? Geophys Res Lett 20: 1955-1958.

Menéndez M, Woodworth PL (2010) Changes in extreme high water levels based on a quasiglobal tide-gauge dataset. J Geophys Res 115: C10011, doi:10.1029/2009JC005997.

Merrifield MA, Merrifield ST, Mitchum GT (2009a) An anomalous recent acceleration of global sea level rise. J Clim 22: 5772-5781, doi: 10.1175/2009JCLI2985.1.

Merrifield MA, Nerem RS, Mitchum GT, Miller L, Leuliette E, Gill S, Woodworth PL (2009b) Sea level variations, 2008 annual assessment. In: State of the Climate in 2008. Bull Am Meteorol Soc 90: S62-S65.

Miller L, Douglas BC (2007) Gyre-scale atmospheric pressure variations and their relation to 19th and 20th century sea level rise. Geophys Res Lett 34 : L16602, doi:10.1029/GL030862.

Milne GA, Gehrels WR, Hughes CW, Tamisiea ME (2009) Identifying the causes of sea-level change. Nature Geoscience 2: 471-478, doi:10.1038/NGEO544.

Mitchum GT, Nerem RS, Merrifield MA, Gehrels WR (2010) Modern Sea-Level-Change Estimates. Chapter 5 in, Understanding sea-level rise and variability (eds. J.A. Church, P.L. Woodworth, T. Aarup and W.S. Wilson). Wiley-Blackwell (London).

Mitrovica JX, Tamisiea ME, Milne GA, Davis JL (2001) Recent mass balance of polar ice sheets inferred from patterns of global sea-level change. Nature 409: 1026-1029.

Mitrovica JX, Tamisiea ME, Ivins ER, Vermeersen LLA, Milne GA, Lambeck K (2010) Surface mass loading on a dynamic Earth: complexity and contamination in the geodetic analysis of global sea-level trends. Chapter 10 in, Understanding sea-level rise and variability (eds. J.A. Church, P.L. Woodworth, T. Aarup and W.S. Wilson). Wiley-Blackwell (London).

Moron V, Ullmann A (2005) Relationship between sea-level pressure and sea-level height in the Camargue (French Mediterranean coast). Int J Climatol 25: 1531-1540, doi:10.1002/joc.1200.

Erratum in 2006, Int J Climatol, 26: 987, doi:10.1002/joc.1320.

Mudersbach C, Jensen J (2010) Nonstationary extreme value analysis of annual maximum water levels for designing coastal structures on the German North Sea coastline. J Flood Risk Manag 3: 52-62, doi:10.1111/j.1753-318X.2009.01054.X.

NTC (National Tidal Centre) (2009) The Australian baseline sea level monitoring project. Annual sea level data summary report, July 2008 - June 2009. National Tidal Centre, Australian Bureau of 
Meteorology, Kent Town, South Australia. 41pp. Available from http://www.bom.gov.au/ntc/IDO60202/IDO60202.2009.pdf.

Pouvreau N (2008) Trois cents ans de mesures marégraphiques en France: outils, méthodes et tendances des composantes du niveau de la mer au port de Brest, $\mathrm{PhD}$ thesis, University of La Rochelle, 2008.

Prandi P, Cazenave A, Becker M (2009) Is coastal mean sea level rising faster than the global mean? A comparison between tide gauges and satellite altimetry over 1993-2007. Geophys Res Lett 36: L05602, doi:10.1029/2008GL036564.

Rahmstorf S, Cazenave A, Church JA, Hansen JE, Keeling RF, Parker DE, Somerville RCJ (2007) Recent climate observations compared to projections. Science 316: 709, doi:10.1126/science. 1136843 .

Raicich F (2007) A study of early Trieste sea level data (1875-1914). J Coast Res 23: 1067-1073, doi: $10.2112 / 04-0325.1$.

Ray RD (2009) Secular changes in the solar semidiurnal tide of the western North Atlantic Ocean. Geophys Res Lett 36: L19601, doi:10.1029/2009GL040217.

Testut L, Wöppelmann G, Simon B, Téchiné P (2006) The Sea Level at Port-aux-Français, Kerguelen Island, from 1950 to the present. Ocean Dyn 56(5-6), doi 10.1007/s10236-005-0056-8.

Testut L Martin Miguez B, Wöppelmann G, Tiphaneau P, Pouvreau N, Karpytchev M (2010) Sea level at Saint Paul Island, Southern Indian Ocean, from 1874 to the present. J Geophys Res, doi:10.1029/2010JC006404, in press.

Thompson KR, Bernier NB, Chan P (2009) Extreme sea levels, coastal flooding and climate change with a focus on Atlantic Canada. Nat Hazards 51: 139-150, doi:10.1007/s11069-009-93805 .

Tsimplis MN, Baker TF (2000) Sea level drop in the Mediterranean Sea: an indicator of deep water salinity and temperature changes? Geophys Res Lett 27: 1731-1734.

Tsimplis MN, Marcos M, Pérez B, Challenor P, Garcia-Fernandez MJ, Raicich F (2009) On the effect of the sampling frequency of sea level measurements on return period estimate of extremes Southern European examples. Cont Shelf Res 29: 2214-2221, doi:10.1016/j.csr.2009.08.015.

Tsimplis MN, Shaw AGP (2010) Seasonal sea level extremes in the Mediterranean Sea and at the Atlantic European coasts. Nat Hazards Earth Syst Sci 10: 1457-1475, doi:10.5194/nhess-10-14572010.

Ullmann A, Pirazzoli PA, Tomasin A (2007) Sea surges in Camargue: trends over the 20th century. Cont Shelf Res 27: 922-934, doi:10.1016/j.csr.2006.12.001.

Ullmann A, Moron V (2008) Weather regimes and sea surge variations over the Gulf of Lions (French Mediterranean coast) during the 20th century. Int J Climatol 28: 159-171, doi:10.1002/joc. 1527.

Ullmann A, Pirazzoli PA, Moron V (2008) Sea surges around the Gulf of Lions and atmospheric conditions. Glob Planet Chang 63: 203-214, doi:10.1016/j.gloplacha2007.10.002.

Ullmann A, Monbaliu J (2010) Changes in atmospheric circulation over the North Atlantic and sea-surge variations along the Belgian coast during the twentieth century. Int J Climatol 30: 558 568, doi:10.1002/joc. 1904 .

Vilibić I, Šepić J (2009) Long-term variability and trends of sea level storminess and extremes in European Seas. Glob Planet Chang 71: 1-12, doi:10.1016/j.gloplacha.2009.12.001. 
Wake LM, Milne GA, Leuliette E (2006) 20th Century sea-level change along the eastern US: unravelling the contributions from steric changes, Greenland ice sheet mass balance and Late Pleistocene glacial loading. Earth Planet Sci Lett 250: 572-580, doi:10.1016/j.eps1.2006.08.006.

Watson C, Burgette R, Tregoning P, White N, Hunter J, Coleman R, Handsworth R, Brolsma H (2010) Twentieth century constraints on sea level change and earthquake deformation at Macquarie Island. Geophys J Int 182: 781 - 796, doi:10.1111/j.1365-246X.2010.04640.x.

White NJ, Church JA, Gregory JM (2005) Coastal and global averaged sea level rise for 1950 to 2000. Geophys Res Lett 32: L01601, doi:10.1029/2004GL021391.

Woodworth PL (1990) A search for accelerations in records of European mean sea level. Int J Climatol 10: 129-143.

Woodworth PL (1999) High waters at Liverpool since 1768: the UK's longest sea level record. Geophys Res Lett 26: 1589-1592.

Woodworth PL, Player R (2003) The Permanent Service for Mean Sea Level: an update to the 21st century. J Coast Res19: 287-295.

Woodworth PL, Aarup T, Merrifield M, Mitchum GT, Le Provost C (2003) Measuring progress of the Global Sea Level Observing System. EOS, Transactions of the American Geophysical Union, 84(50), 16 December 2003, 565, 10.1029/2003EO500009.

Woodworth PL, Blackman DL (2004) Evidence for systematic changes in extreme high waters since the mid-1970s. J Clim 17: 1190-1197, doi:10.1175/1520-0442.

Woodworth PL, White NJ, Jevrejeva S, Holgate SJ, Church JA, Gehrels WR (2009a) Evidence for the accelerations of sea level on multi-decade and century timescales. Int J Climatol 29: 777-789, doi:10.1002/joc. 1771 .

Woodworth P, Foden P, Pugh J, Mathews A, Aarup T, Aman A, Nkebi E, Odametey J, Facey R, Esmail MYA, Ashraf M (2009b) Insight into long term sea level change based on new tide gauge installations at Takoradi, Aden and Karachi. Int Hydrogr Rev No.1 (May 2009), 18-23. (http://www.iho-ohi.net/mtg_docs/IHReview/2009/IHR_May2009_Article02_1.pdf)

Woodworth PL, Pugh DT, Bingley RM (2010a) Long term and recent changes in sea level in the Falkland Islands. J Geophys Res 115: C09025, doi:10.1029/2010JC006113.

Woodworth PL, Pouvreau N, Wöppelmann G (2010b) The gyre-scale circulation of the North Atlantic and sea level at Brest. Ocean Sci 6: 185-190.

Woodworth PL (2010) A survey of recent changes in the main components of the ocean tide. Cont Shelf Res 30: 1680-1691, doi:10.1016/j.csr.2010.07.002.

Wöppelmann G, Pouvreau N, Coulomb A, Simon B, Woodworth P (2008) Tide gauge datum continuity at Brest since 1711: France's longest sea-level record. Geophys Res Lett 35: L22605, doi:10.1029/2008GL035783. 


\section{Figure Legends}

1(a). Long sea level records from northern Europe. The Brest record is a mean sea level time series derived from mean high waters as described by Pouvreau (2008) and Woodworth et al. (2010b). The Liverpool series has been derived in a similar manner using the 'adjusted mean high waters' of Woodworth (1999). These two records are denoted by 'HC' ('high water computation') and are shown in red. The Den Helder record shown in black has been adjusted to have the same mean value as Amsterdam for the period of overlap. The vertical scale is indicated by the $\pm 100 \mathrm{~mm}$ error bars. The six time series yield 'c' coefficient values of $0.0037 \pm 0.0002,0.0015 \pm 0.0005$, $0.0091 \pm 0.0015,0.0057 \pm 0.0008,0.0036 \pm 0.0010$ and $0.0049 \pm 0.0012 \mathrm{~mm} /$ year $^{2}$ respectively, top to bottom.

(b) Records starting in the mid- $19^{\text {th }}$ century for 4 stations in Germany (in blue) and 2 in North America (in red). The vertical scale is indicated by the $\pm 100 \mathrm{~mm}$ error bars. The six time series yield 'c' coefficient values of $0.0037 \pm 0.0016,0.0014 \pm 0.0014,0.0005 \pm 0.0014,0.0062 \pm$ $0.0020,0.0038 \pm 0.0014$ and $0.0069 \pm 0.0019 \mathrm{~mm} /$ year $^{2}$ respectively, top to bottom. The black lines are separate linear fits to $19^{\text {th }}$ and $20^{\text {th }}$ century data, as a guide to any acceleration between the centuries.

2. Large dots indicate values of corrected sea level (SLC, i.e. sea level corrected for air pressure effects and for the seasonal cycle in SLC) at and near to Port Louis in the Falkland Islands. Values are shown relative to the height of the main ('Ross') benchmark. The star indicates SLC during a fortnight measurement period at Port Louis in February-March 2009. Also shown are monthly mean values of SLC from the permanent tide gauge station at Port Stanley that have been related to those at Port Louis with the use of overlapping data sets. The dash-dotted trend line connects the 1842 value to the 1981-2 and 1984 values, while the solid line is a linear fit to the Port Stanley SLC data since 1992 extrapolated back to the early 1980s. (Adapted from Woodworth et al. 2010a).

3. A schematic compilation of sea level records obtained from saltmarshes demonstrating $19^{\text {th }}-20^{\text {th }}$ century accelerations in both hemispheres but with possibly different timing of 'inflexions' at different locations. (Figure updated from that in Gehrels 2010. See the text for the individual references).

4. Estimated trends in (top) annual $99^{\text {th }}$ percentile of sea level, (middle) $99^{\text {th }}$ percentile reduced to medians, and (bottom) $99^{\text {th }}$ percentile of the non-tidal residual. Only trends at confidence level above $95 \%$ are shown by larger colour dots: red for positive and blue for negative trends. (Adapted from Menéndez and Woodworth 2010).

5. Estimated changes in the frequency of extreme sea level events for (a) the measured sea level time series, and (b) for time series with annual median removed. Changes are the annual percentage of increase/decrease in the occurrence of extreme events relative to the average occurrence rate. Small black dots indicate trends with a confidence level below 95\%. (Adapted from Menéndez and Woodworth 2010). 


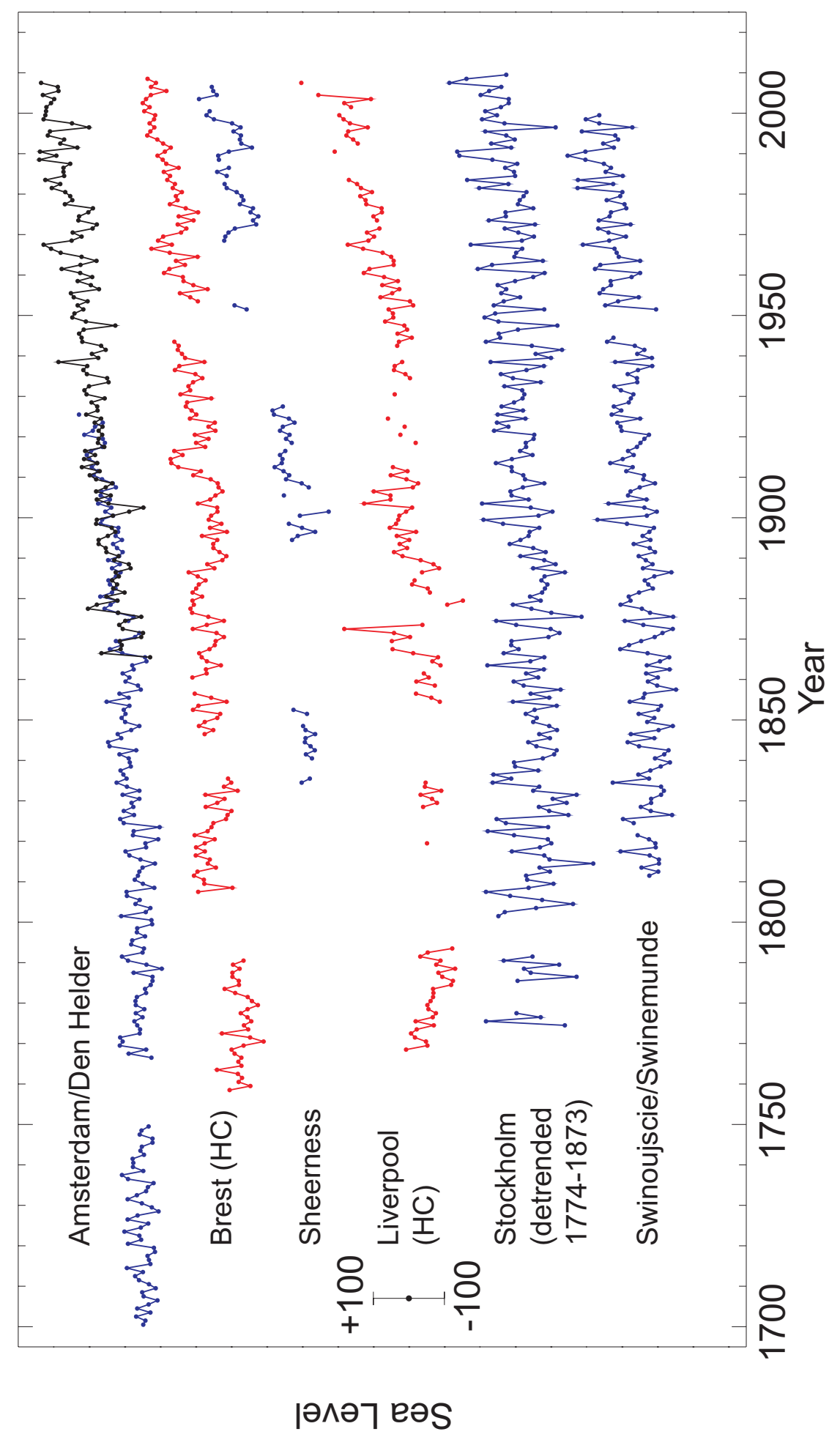

Figure 1(a) 


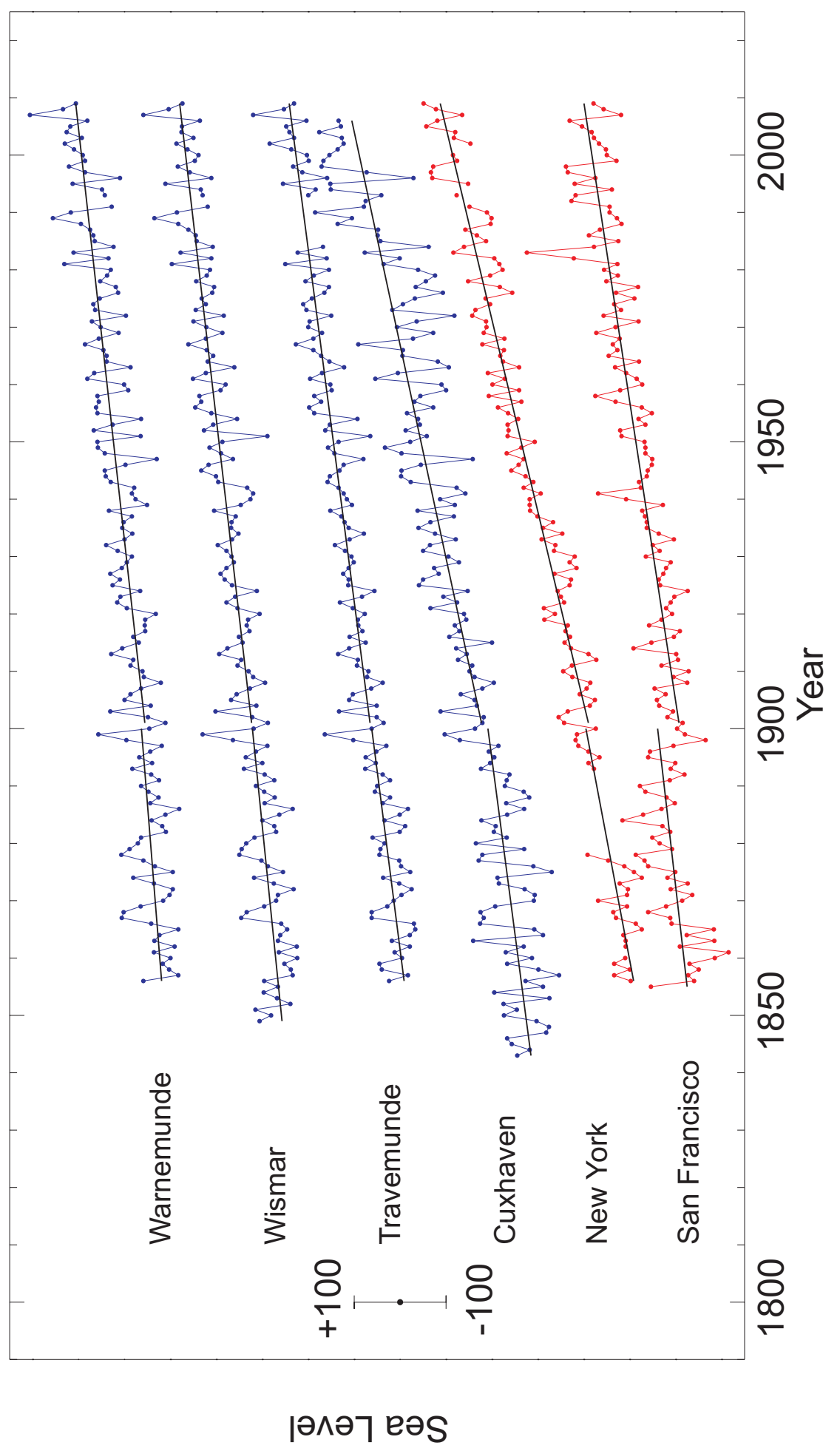

Figure 1(b) 


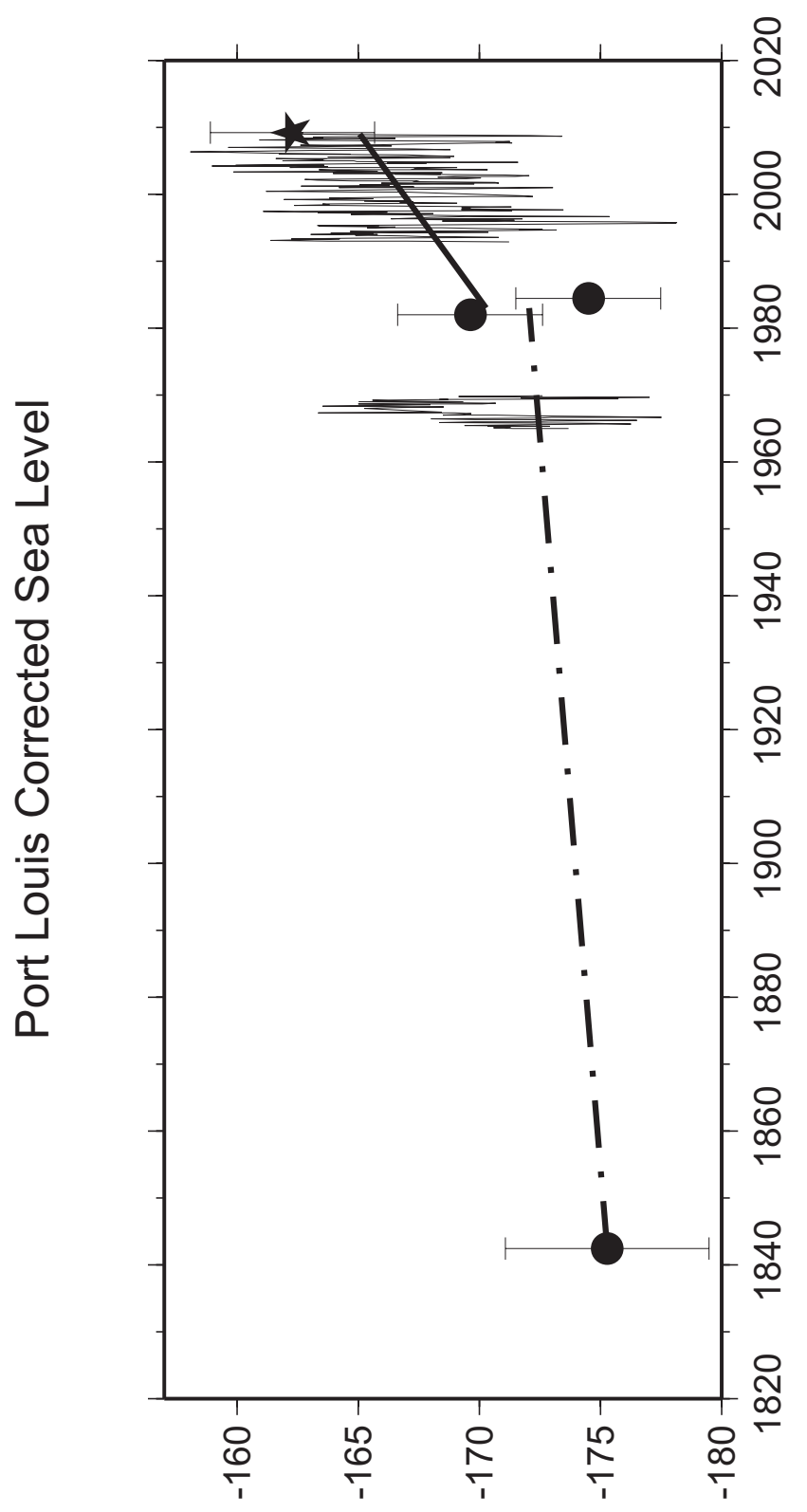

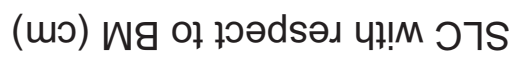

Figure 2 


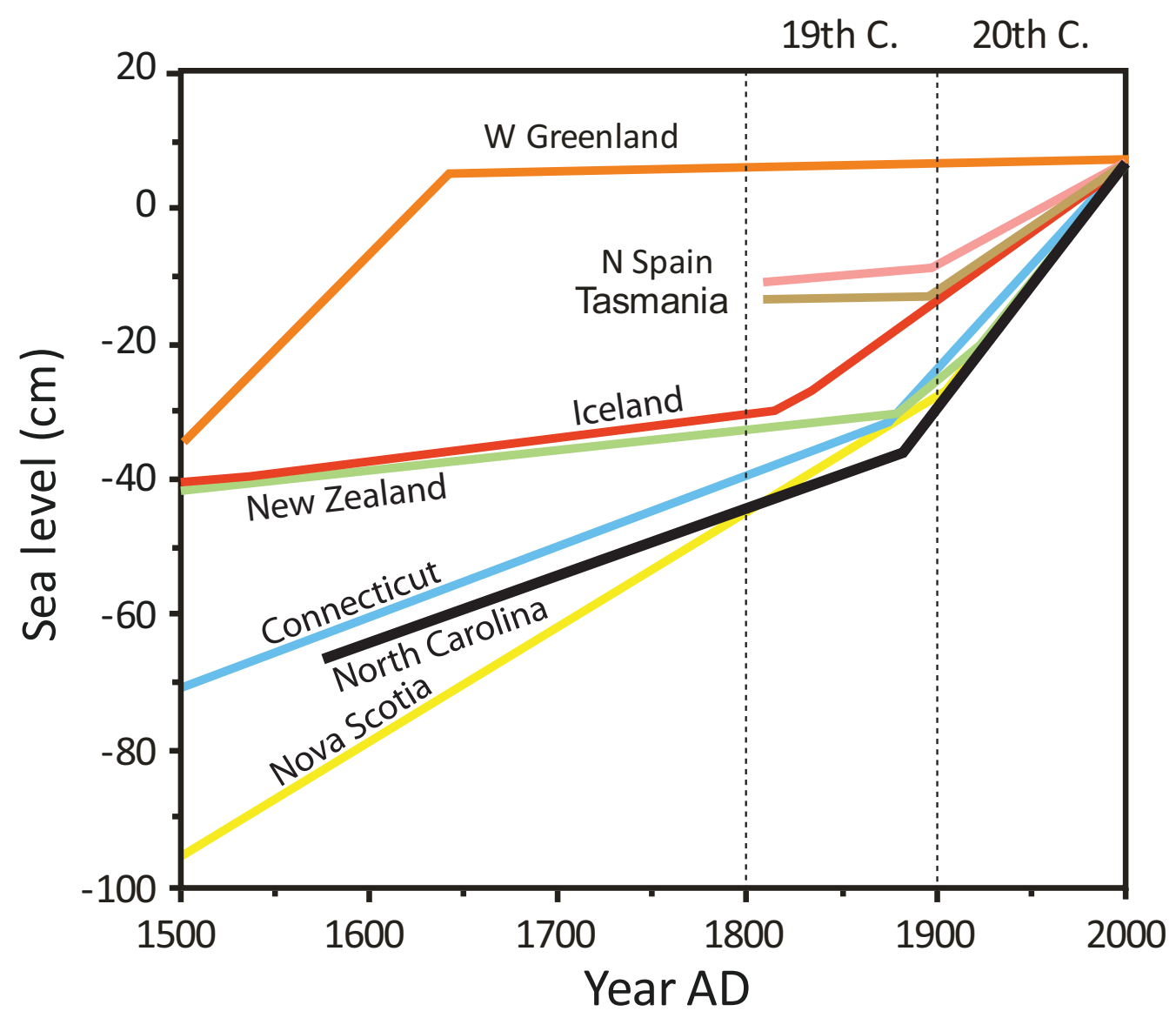

Figure 3 

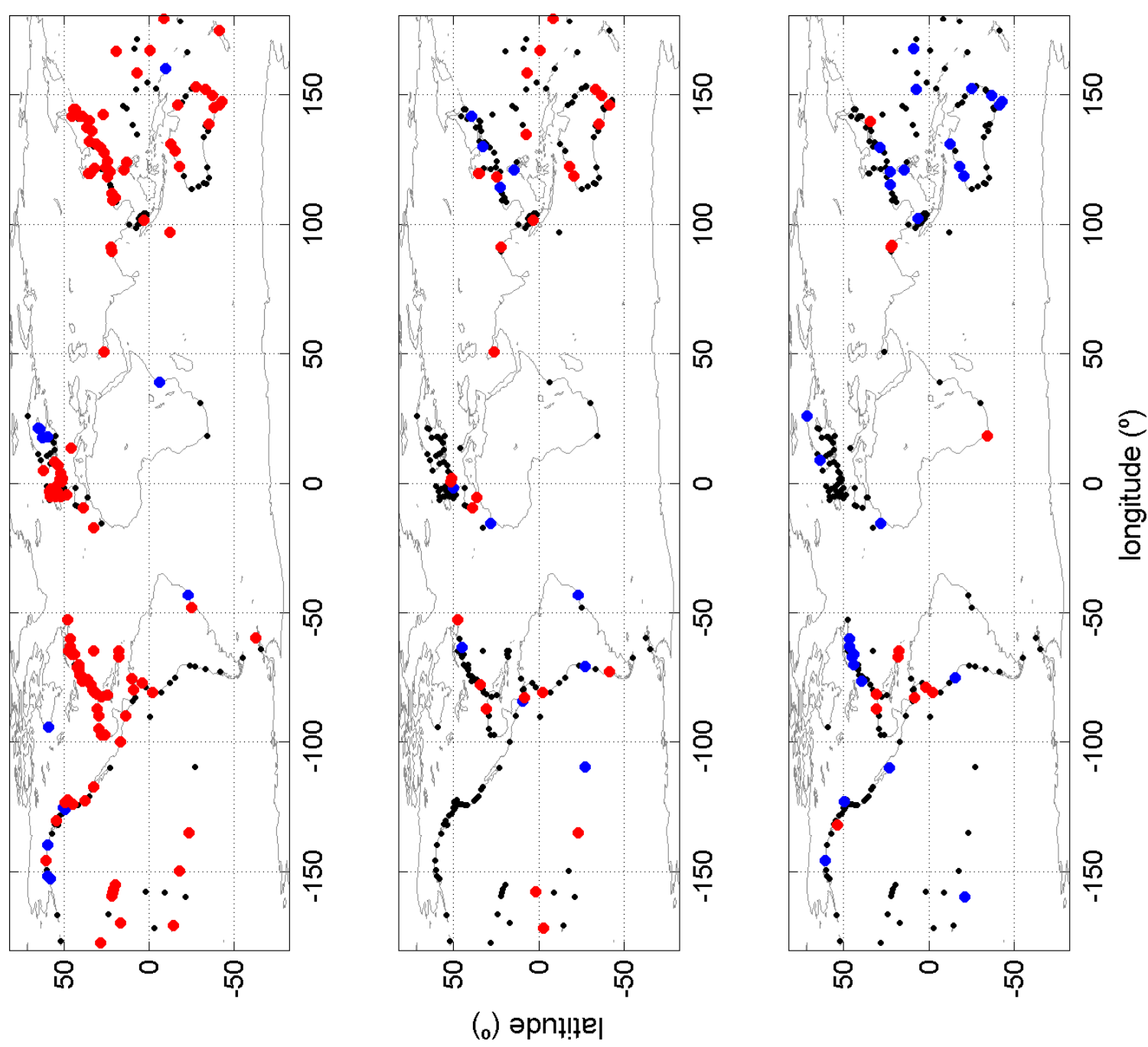

Figure 4 


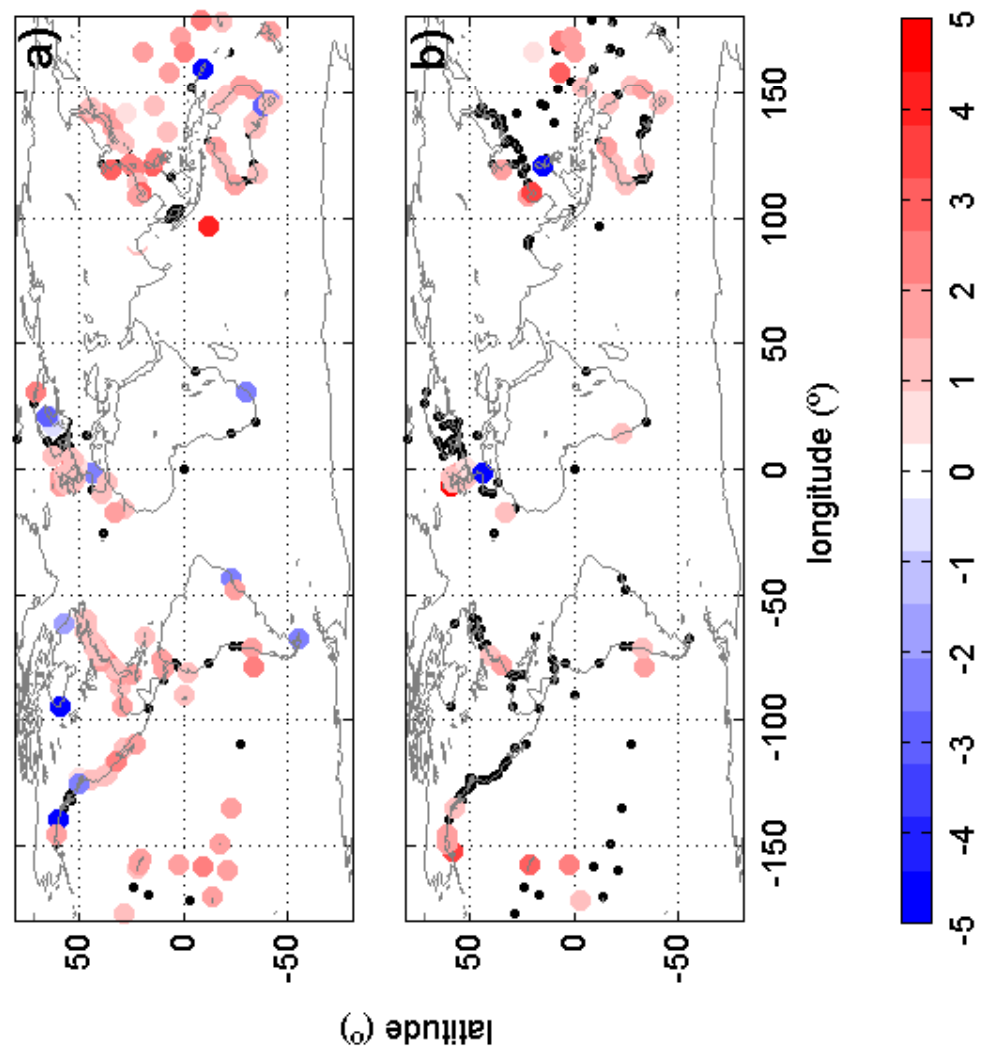

Figure 5 